\title{
Langerhans Cells in the Larynx and the Hypopharynx
}

\author{
KIMINORI SATO AND MINORU HIRANO \\ Department of Otolaryngology-Head and Neck Surgery, \\ Kurume University School of Medicine, Kurume 830, Japan
}

Received for publication September 11, 1997

\begin{abstract}
Summary: Langerhans cells are important in the human immune system as a part of the dendritic cell system. This study was carried out to demonstrate the presence of Langerhans cells and their distribution in normal human larynx and hypopharynx, by light (S-100 polyclonal antibody) and transmission electron microscopy. The results are summarized as follows: 1) Langerhans cells with cytoplasmic granules (Langerhans granules or Birbeck's granules) were situated in the suprabasal region of the squamous epithelium in the larynx and the hypopharynx. 2) They distributed in the membranous portion of the vocal folds, epiglottis, aryepiglottic folds, arytenoid regions and interarytenoid notch of the larynx. The cells surrounded the vestibule and glottis of the larynx. 3) They distributed in the postcricoid area, piriform sinus and posterior pharyngeal wall of the hypopharynx. The cells were situated above the entrance of esophagus. 4) The cells were suggested to be a factor of immune response at the entrance of trachea and esophagus.
\end{abstract}

Key words Langerhans cell, immunology of larynx and hypopharynx, histology of larynx and hypopharynx, vocal folds, larynx, hypopharynx

\section{Introduction}

Langerhans cells are important in the human immune system as a part of the dendritic cell system (Romani and Schuler, 1992). Dendritic cells are a system of antigen presenting cells and have an ability to capture antigens and initiate $\mathrm{T}$ cell-mediated immunity (Steinman, 1991).

Schenk (1980) demonstrated the presence of Langerhans cells in squamous cell carcinoma of the larynx identified by ultrstructural examination of cytoplasmic granules (Langerhans granules or Birbeck's granules). Gallo et al. (1991) noted the presence of Langerhans cells in squamous cell carcinoma of the larynx using the polyclonal antibody against S-100 protein. Thompson and Griffin (1994) noted Langerhans cells in normal and pathological vocal fold mucosa, using the S-100 polyclonal antibody.

Demonstration of the presence and distribution of Langerhans cells in normal human larynx and hypopharynx

Reprint requests to: Kiminori Sato, M.D., Department of Otolaryngology-Head and Neck Surgery, Kurume University School of Medicine, 67 Asahi-machi, Kurume 830, Japan.

TEL: 81-942-35-3311 ext. 3592 FAX: 81-942-37-1200 
is but little reported. The purposes of this study were to demonstrate the presence of Langerhans cells and their distribution in the normal human larynx and hypopharynx.

\section{Materials and Methods}

Seven normal human larynges and hypopharynges obtained from autopsy cases were used. Four of these were from men with ages ranging from 45 to 56 , and 3 from women with ages ranging from 43 to 58. They didn't suffer from diseases of larynx and hypopharynx and immunologic disorder.

Langerhans cells can be detected histologically in formalin fixed and paraffin embedded tissue expression S-100 protein on immunohistochemistry. For the present immunohistochemistry study, 4 specimens were fixed in $10 \%$ formalin. Serial sections were made. They were dehydrated in graded concentrations of ethanol, embedded in paraffin and stained with S-100 polyclonal antibody (DAKO corporation, USA, 1:500) using a labeled streptavidin biotin (LSAB) technique (DAKO LSAB kit).

For the transmission electron microscopic study, three specimens were fixed in $2.5 \%$ glutaraldehyde at $4{ }^{\circ} \mathrm{C}$ for 2 hs. After being rinsed with cacodylate buffer solution, they were postfixed in $2 \%$ osmium tetroxide with Millonig's phosphate buffer solution at $4{ }^{\circ} \mathrm{C}$ for 2 hs. This was followed by dehydration in graded concentrations of ethanol and embedding in epoxy resin. Semithin sections were made with an ultramicrotome, stained with $1 \%$ toluidine blue and examined by light microscopy. Thin sections were made with an ultramicro- tome, stained with uranyl acetate and lead citrate and observed under a JEM2000EX transmission electron microscope.

\section{Results}

Morphologic findings of the Langerhans cells in the larynx and hypopharynx

Figures $1 \mathrm{~A}$ and $1 \mathrm{~B}$ show light microscopic findings of Lagerhans cells in the larynx and the hypopharynx. They were present in squamous epithelium in the larynx and the hypopharynx, as shown using the S-100 polyclonal antibody. They were dendritic in shape (Figs $1 \mathrm{~A}$ and $\mathrm{B}$ ) and situated in the suprabasal region of the squamous epithelium (Fig. 1A).

Figures 1C-E show transmission electron microscopic findings of Langerhans cells. They were dendritic in shape. They possessed clear cytoplasm (Figs 1C and D) which contained no tonofilaments (Figs 1C and D). Desmosomes were absent between keratinocytes (Figs $1 C$ and D). The nuclei were markedly folded and the nucleoplasm was relatively clear (Fig. 1D). Golgi apparatus,.mitochondria and rough endoplasmic reticulum were seen in the cytoplasm. Some cytoplasmic granules (Langerhans granules or Birbeck's granules) showing rod-shaped and median striated lines in the cytoplasm could be seen (Fig. 1E). The size of these granules was approximately $40 \mathrm{~nm}$ in width and $200 \mathrm{~nm}$ in length. Occasionally lysosomes containing melanin granules were present in Langerhans cells (Fig. 1D).

Distribution of the Langerhans cells in the larynx and the hypopharynx

In the larynx, the Langerhans cells 


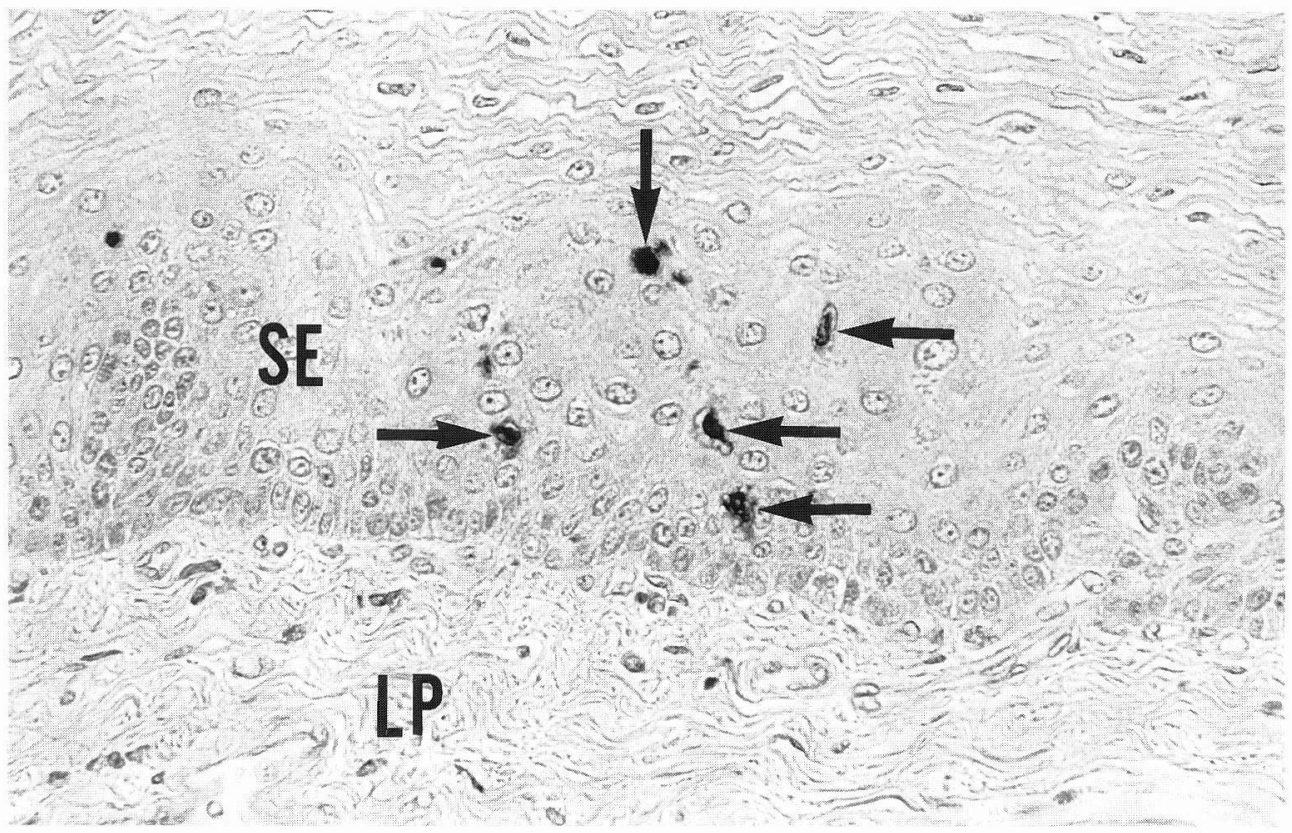

Fig. 1A. Langerhans cells in the squamous epithelium at arytenoid of the larynx. (S-100 antibody stain, original $\times 100$ ) arrow: darkly staining Langerhans cells, SE: squamous epithelium, LP: lamina propria

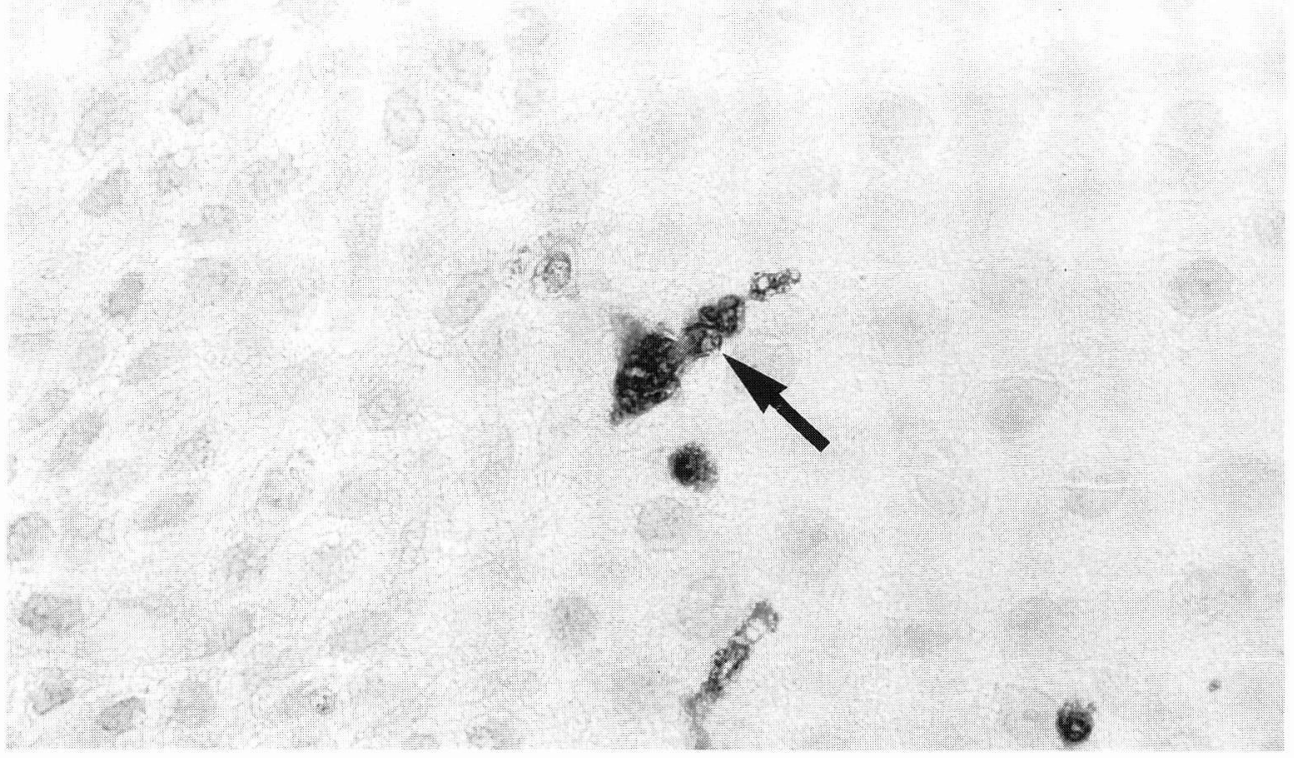

Fig. 1B. Langerhans cells in the squamous epithelium at piriform sinus of the hypopharynx. (S-100 antibody stain, original $\times 400$ ) arrow: darkly staining Langerhans cells. 


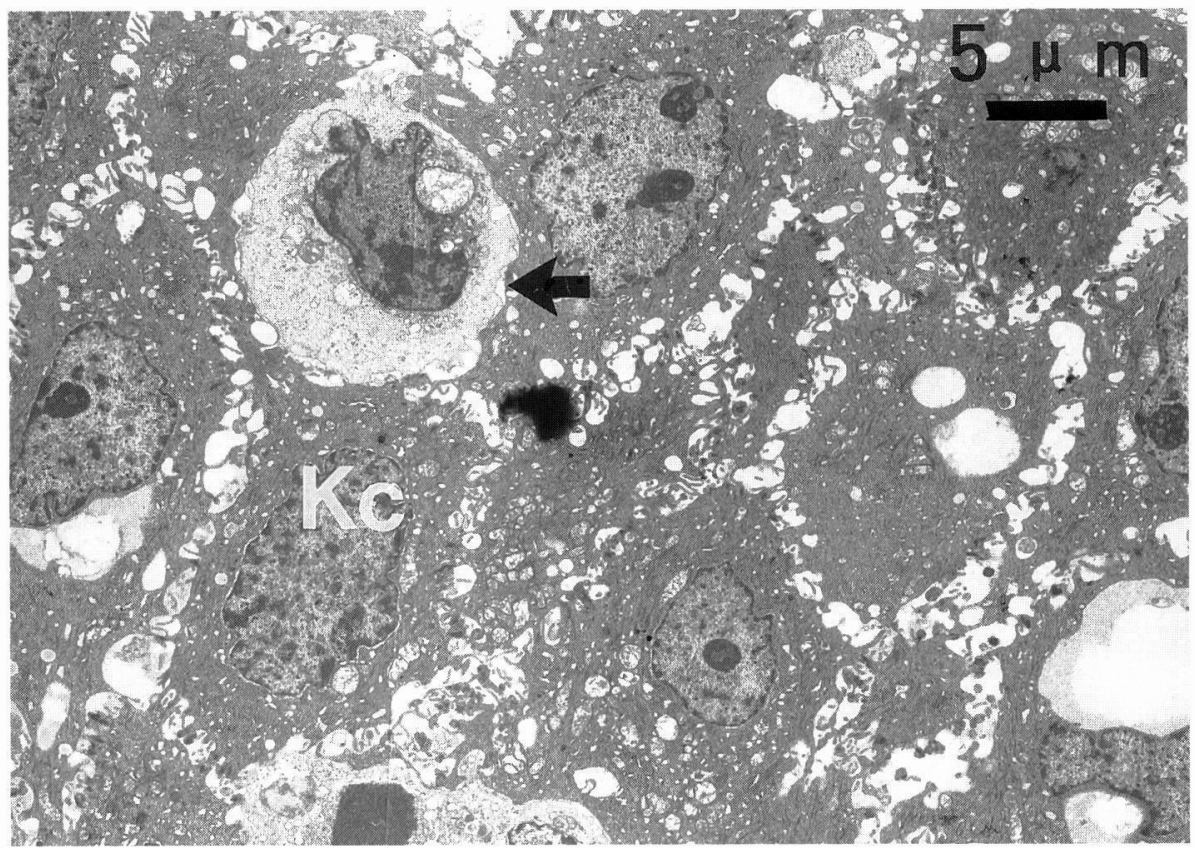

Fig. 1C. Transmission electron microscopic (TEM) findings of Langerhans cells in the squamous epithelium at postcricoid area of the hypopharynx. arrow: Langerhans cells, Kc: keratinocyte

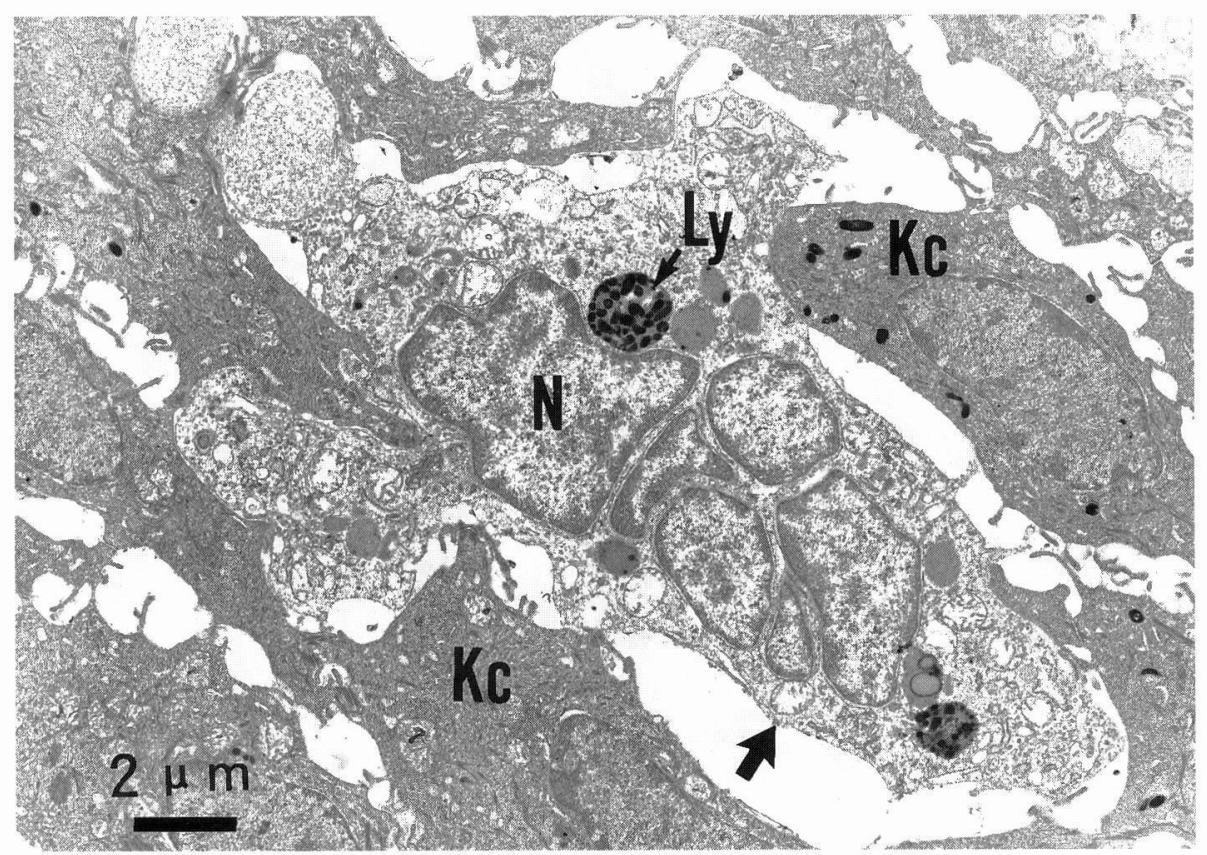

Fig. 1D. TEM findings of Langerhans cells in the squamous epithelium at vocal fold of the larynx. arrow: Langerhans cells, Ly: lysosomes, $\mathrm{N}$ : nucleus, Kc: keratinocyte 


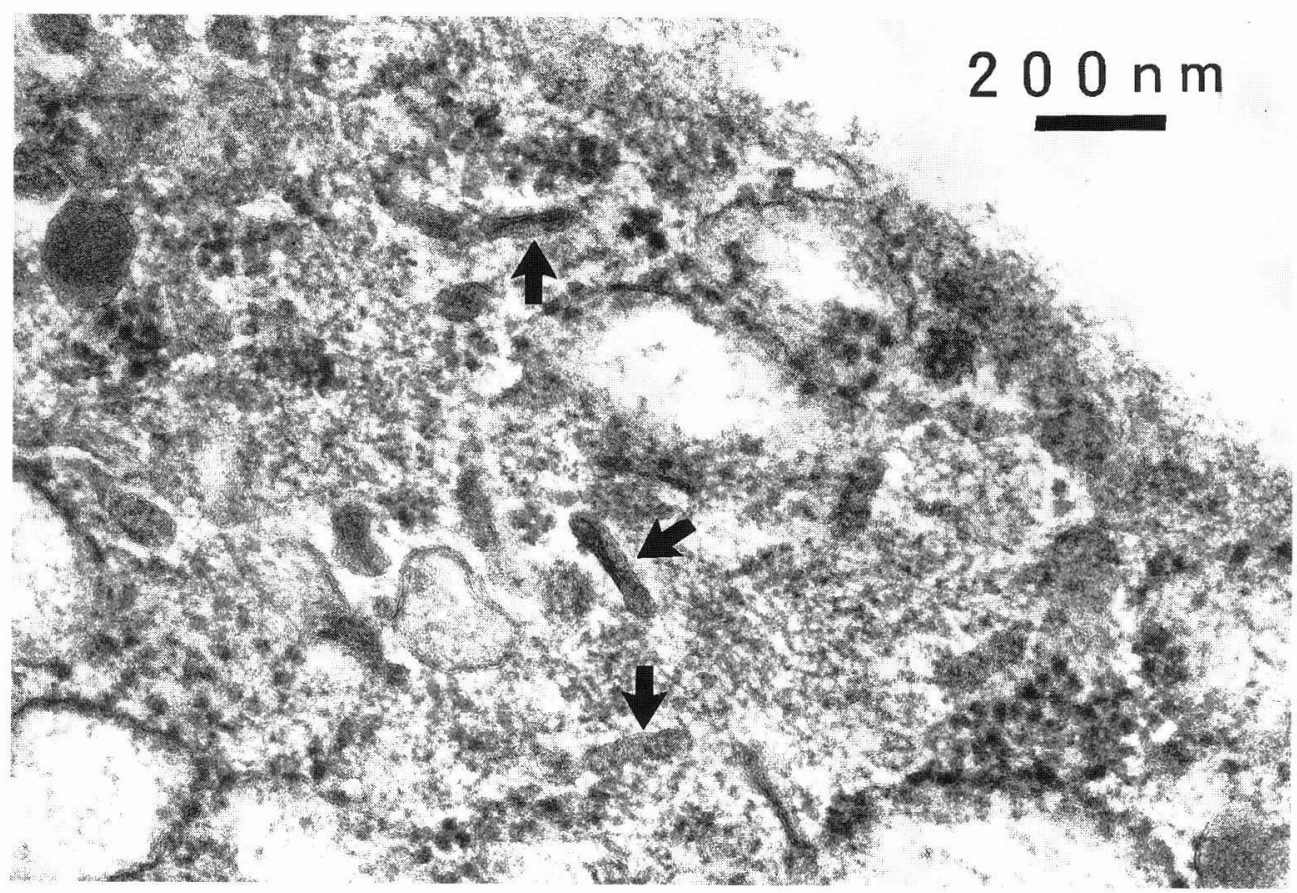

Fig. 1E. TEM findings of cytoplasmic granules in Langerhans cells. arrow: cytoplasmic granules (Birbeck's granules).

were present in squamous epithelium in the epiglottis, aryepiglottic folds, arytenoid regions, interarytenoid notch and membranous portion of the vocal folds. They surrounded the vestibule and glottis of the larynx. In the hypopharynx, they were situated in squamous epithelium in the postcricoid area, piriform sinus and posterior pharyngeal wall of the hypopharynx.

\section{Discussion}

Langerhans cells are important component of the human immune system as a part of the dendritic cell system. Dendritic cells constitute a system of antigen-presenting cells widely distributed throughout the body and have a outstanding capacity to initiate primary immune response (Romani and Schuler, 1992). They acquire antigens in the tissues and process them in an immunogenic form (Romani and Schuler, 1992). They convey immunogens to lymphoid organs and detect and efficiently activate antigen-specific $\mathrm{T}$ cell clones to generate immune response (Romani and Schuler, 1992). Dendritic cells comprise a system that occupies discrete portions of nonlymphoid and lymphoid organs (Steinman, 1991). Langerhans and interstitial dendritic cells constitute the dendritic cell system in nonlymphoid organs (Steinman, 1991). 
Langerhans cells characterized by the presence of cytoplasmic granules (Langerhans granules or Birbeck's granules) have been detected not only in the epidermis (Birbeck et al. 1961; Breathnach, 1964) but nose (Jahnke, 1974), oral cavity (Schroeder and Theilade, 1966) and cervix uteri (Hackermann et al. 1968) of humans. Langerhans cells are present under both normal as well as pathological conditions (Hammar et al. 1986). Regarding the larynx, Schenk (1980) observed Langerhans cells in squamous cell carcinoma of the larynx, identified by ultrastructures of cytoplasmic Birbeck's granules. Gallo et al. (1991) noted Langerhans cells in the squamous cell carcinoma of the larynx using the polyclonal antibody against S100 protein, concluded that the presence of high or intermediate density of Langerhans cells and of marked lymphoid inflammation may be considered favorable prognostic factors for patients with squamous cell carcinoma of the larynx. Thompson and Griffin (1994) reported Langerhans cells in normal and pathological vocal folds, using the S-100 polyclonal antibody. Regarding the hypopharynx, Langerhans cells in it were little reported. Demonstration of the presence and distribution of Langerhans cells in normal human larynx and hypopharynx remain unclear. Langerhans cells were shown in this study to be characterized by the presence of cytoplasmic granules (Langerhans or Birbrck's granules) using an electron microscope in normal human larynx and hypopharynx; their distribution was also clarified.

There are immunological resistance of mucosa, i.e., local, humoral and cellular immunity. Mogi et al. (1979) studied the biological properties of laryngeal secretion and found laryngeal secretions to contained IgG, IgA, IgE, secretory components and lactoferrin. They emphasize the importance of the local immune system by secretory IgA in the laryngeal mucosa. Humoral immunity, components are immunogloblins present throughout the body, is in the larynx. Langerhans cells presented in this study, macrophage and $\mathrm{T}$ cells are important component of cellular immunity. Brandtzaeg (1995) reported three principles involved in defense of airway mucosa. 1. Immune exclusion which limits epithelial colonization of microorganisms and inhibits the entrance of foreign material. Locally produced secretory IgA and secretory IgM, and IgG antibodies that seep through the epithelium are responsible for immune exclusion. 2. Immune regulation which requires interactions between antigen presenting cells (dendritic cells, macrophages), T cells, and $\mathrm{B}$ cells. 3. Immune elimination for the neutralization and elimination of foreign material that has penetrated through the epithelium. This second line of defense is triggered by cytokines, activated $\mathrm{T}$ cells and antibodies. Langerhans cells in the larynx and the hypopharynx may possibly be essential to immune regulation required for defense of mucosa of the airway and the passageway of food.

There may be such a thing as laryngeal allergy. Williams (1972) reported allergic laryngitis. Lagerhans cells in the larynx and the hypopharynx may participate in allergic reaction as antigen presenting cells.

This study indicated Lagerhans cells to be distributed in squamous epithelium 
in the epiglottis, aryepiglottic folds, arytenoids, interarytenoid notch and membranous portion of the vocal fold. They surround the vestibule and glottis of the larynx. They were suggested to be essential to immune response at the entrance of trachea. Basic functions of the larynx are acting as a protective sphincter, passageway for air and soundproduction. The larynx is suggested to be essential for immune response in upper respiratory passages. This study also indicated Langerhans cells to be situated in squamous epithelium in the postcricoid area, piriform sinus and posterior pharyngeal wall of the hypopharynx. They were suggested to be essential to immune response above the entrance of esophagus in upper digestive system.

Acknowledgments: We are grateful to Dr. Yuuji Ito and Dr. Yasuhiro Nakamura, St. Mary's Hospital, Kurume, for their thoughtful contribution of the cadaver larynges.

\section{References}

Birbeck MS, Breathnach AS, and Everall JD. An electron microscopic study of basal melanocytes and high-level clear cells (Langerhans cells) in vitiligo. $\mathrm{J}$ Invest Derm 1961; 37:51-64.

Brandtzaeg P. Immunocompetent cells of the upper airway: functions in normal and diseased mucosa. Eur Arch Otorhinolaryngol 1995; 252 (Suppl 1):S8-S21.

Breathnach AS. Observations on cytoplasmic organelles in Langerhans cells of human epidermis. J Anat Lond 1964; 98:265-270.

Gallo O, Libonati GA, Galiina E, Fini-Storchi $\mathrm{O}$, Giannini A et al. Langerhans cells related to prognosis in patients with laryngeal carcinoma. Arch Otolaryngol Head Neck Surg 1991; 117:1007-1010.

Hackermann M, Grubb C, and Hill KR. The ultrastructure of normal squamous epithelium of the human cervix uteri. J Ultrastruct Res 1968; 22:443-457.

Hammar S, Bockus D, Remington F, and Bartha M. The widespread distribution of Langerhans cells in pathologic tissues. Hum Pathol 1986; 17:894-905.

Jahnke V. Elektronenmikroskopische Befunde am normalen menschlichen Nasenrachenepithel. Laryngol Rhinol 1974; 53:290-300.

Mogi G, Watanabe N, Maeda S, and Umehara T. Laryngeal secretions. An immunochemical and immunohistological study. Acta Otolaryngl 1979; 87:129-141.

Romani N, and Schuler G. The immunologic properties of epidermal Langerhans cells as a part of the dendritic cell system. Springer Semin Immunopathol 1992; 13:265-279.

Schenk P. Langerhanszellen bei invasivem Larynxkarzinom. Laryngol Rhinol 1980; 59: 232-237.

Schroeder HE, and Theilade J. Electron microscopy of normal human gingival epithelium. J Periodont Res 1966; 1:95-119.

Steinman RM. The dendritic cell system and its role in immunogenicity. Annu Rev Immunol 1991; 9:271-296.

Thompson AC, and Griffin NR. Langerhans cells in normal and pathological vocal cord mucosa. Acta Otolaryngol (Stockh) 1994; 115: 830-832.

Williams RI. Allergic laryngitis. Ann Otol Rhinol Laryngol 1972; 81:558-565. 